\title{
Tracking ore fluid pathways by in situ synchrotron-XRF analysis of fluid inclusions
}

\author{
MORTEZA RABIEI ${ }^{1}$, GUOXIANG CHI ${ }^{1}$, ERIC G. POTTER ${ }^{2}$ \\ AND RENFEI FENG ${ }^{3}$ \\ ${ }^{1}$ University of Regina \\ ${ }^{2}$ Geological Survey of Canada \\ ${ }^{3}$ Canadian Light Source \\ Presenting Author: morteza.rabiei2m@gmail.com
}

The Athabasca Basin (Canada) hosts numerous unconformityrelated $U$ (URU) deposits located along structural corridors that developed at intersections between basement-rooted reverse faults and the basin-basement unconformity. LA-ICP-MS and synchrotron-XRF (SXRF) analyses of fluid inclusions indicate that ore fluid(s) in mineralized zones were significantly enriched in $\mathrm{U}, \mathrm{REEs}$ ( $\mathrm{La}$ and $\mathrm{Ce}$ ), $\mathrm{Br}, \mathrm{Fe}, \mathrm{Sr}$, transition metals ( $\mathrm{Mn}, \mathrm{Ni}$, $\mathrm{Cu}, \mathrm{Zn}$ ) and $\mathrm{Pb}$. However, it is not clear whether this U-rich fluid circulated only in the mineralized zones or along entire corridors, which is important in order to understand the key factors controlling formation of URU deposits.

SXRF analysis indicates that primary fluid inclusions entrapped in syn-ore quartz veins from the McArthur River deposit and P2 fault zone (Fig. 1) contain high $\mathrm{Br}$ and similar concentrations of $\mathrm{U}, \mathrm{Ca}, \mathrm{Sr}$, REEs, base metals and $\mathrm{Zr}$, regardless of proximity to mineralized zones (Fig. 1). This finding is consistent with the basin-scale circulation of U-bearing diagenetic brines which were documented in quartz overgrowth far from URU deposits in the Athabasca sandstone [1]. In addition, the positive correlations between $\mathrm{U}$, base metals (e.g., $\mathrm{Cu}$ in Figs. 1a and $1 \mathrm{~b}$ ), REEs and $\mathrm{Zr}$, suggest a similar origin for these elements along the entire corridor. These results suggest that localization of ore zones in certain segments of the corridors was independent of the geochemical composition of the oreforming fluid(s). We propose that other factors such as permeability and flow rate of U-bearing and/or reducing fluids played more important roles in localizing $\mathrm{U}$ mineralization.

[1] G. Chi, H. Chu, D. Petts, E. Potter, S. Jackson, and A. Williams-Jones (2019), Uranium-rich diagenetic fluids provide the key to unconformity-related uranium mineralization in the Athabasca Basin, Scientific reports, vol. 9, no. 1, p. 5530, 2019.

Fig. 1. Photomicrographs and SXRF elemental maps of fluid inclusion-rich growth zones in drusy quartz veins proximal (a) and distal (b) to the McArthur River URU deposit.

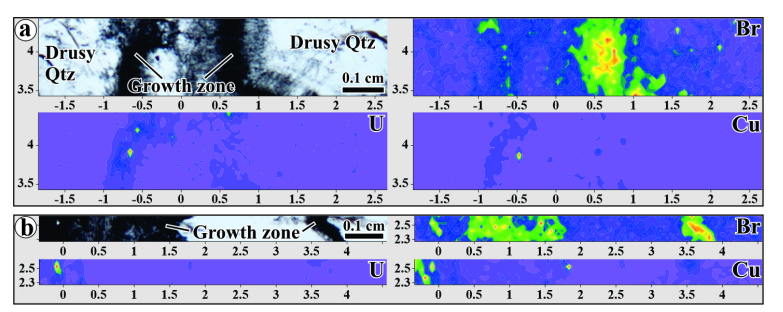

